\title{
PENGARUH EFIKASI DIRI DAN PENDIDIKAN KEWIRAUSAHAANTERHADAP MINAT BERWIRAUSAHA MAHASISWA PADA FAKULTAS KEGURUAN ILMU PENDIDIKAN DI UNIVERSITAS MUHAMADIYAH TANGERANG
}

\author{
${ }^{1}$ Boy Dorahman, ${ }^{2}$ Sa'odah \\ Universitas Muhammadiyah Tangerang \\ 1boydorahman@gmail.com, 2saodah.umt@gmail.com
}

\begin{abstract}
Abstrak
Di Indonesia masalah pengangguran merupakan masalah yang selalu dihadapi dari setiap tahun, salah sa tu penyebabnya a dalah kurangnya la pangan kerja untuk angkatan kerja. Mahasiswa se bagai gen erasi penerus bangsa turut menyumbangkan angka pengangguran diIndonesia karena mahasiswa merupakan calon angkatan kerja yang belum pasti mendapatkan pekerjaan yang sesuai dengan jurusan atau keinginan mereka. Berdasarkan hal tersebut perlu dibangun semangat kewirausaha an untuk meningkatkan ketersediaan lowongan pekerjaan. Hal iini bisa dilakukan dengan menumbu hkan m inat berwirausa ha denga efikasidiri dan pendidikan kewirausahaan. Penelitian inibertujuan un tuk Men gkaji pen garuh pendidikan kewira usahaan terhadap minat berwirausaha, untuk mengkaji pengaruh efikasi diri wira usa ha terhadap minat berwirausaha, untuk mengkajipengaruh pendidikan ke wirausahaan dan efik asi diri terhadap minat berwirausaha. Metode dan desain penelitian dalam pene litian ini menggunakan jenis pendekatan kuantitatif, yang ditujukan untuk menjelaskan pengaru h pendidik an ke wira usahaan d an efika si diri terha dap minat berwirausaha. Pengambilan sample dilakukan dengan cara teknik Convenience Sampling. Dengan menggunakan teknik a nalisis data dalam penelitian ini adalah analisis regresi linier berganda. Penelitian ini menunjukan terdapat pengaruh positif signifikan pen did ikan ke wira u sahaan terhadap minat berwirausaha, terdapat pengaruh positif signifikan efikasi diri terhadap minat berwirau saha mahasiswa, variabel pendidikan kewirausahaan dan efikasi diri secara sim ult an m emiliki penga ruh positif signifikan terhadap minat berwirausaha mahasiswa.
\end{abstract}

Kata kunci: Efikasi Diri, Pendidikan Kewirausahaan, Minat Berwirausaha

\begin{abstract}
In Indonesia the problem of unemployment is a problem always faced from every year, one of the ca use s is the lack of employmentfor the workforce. Students as the next generation of the nation contributed to the unemployment rate in Indonesia because students are candidatesfor the workforce who are not sure to get a job in accordance with their majors or desires. Based on this it is necessary to build entrepreneurial spirit to increase job availability. This can be done by growing entrepreneurial in te rest with self-efficacy and entrepreneurship education.This study aims to examine the influence of entrepreneurship education on entrepreneurship interests, to examine the effect of self-efficacy of entrepreneurship to entrepreneurship interests, to examine the effect of entrepreneurshipeducation and self-efficacy on entrepreneurship interests. Methods and research design in this studyusing the type of quantitative approach, which is intended to explain the influence of entrepreneurship education and self efficacy against entrepreneurial interests. Sampling is doneby Convenience Sampling technique. By using data analysis technique in this research is multiple linear regression analysis.This study shows that there is a significant positive effect of entrepreneurship education on entrepreneurship interest, there is a significant positive effect of selfefficacyon studententrepreneurship interest, entrepreneurship education variable and self efficacy simultaneously have a significant positive effecton studente ntrepreneu rsh ip interest
\end{abstract}

Keywords: SelfEfficacy, Entrepreneurship Education, Interest in Entrepreneurship 


\section{PENDAHULUAN}

Di Indonesia masalah pengangguran merupakan masalah yang selalu dihadapi dari setiap tahun, salah satu penyebabnya adalah kurangnya lapangan kerja untuk an gk atan kerja. Badan Pusat Statistik (BPS) mengungkapkan, pada tahun 2017 telah terjadi kenaikan jumlah pengangguran di Indonesia sebesar 10.000 orang menjadi 7,04 juta orang pada Agustus 2017 dari Agustus 2016 sebesar 7,03 juta orang. Kepala BPS Kecuk Suhariyanto mengatakan, pertambahan jumlah pengangguran tersebut disebabkan oleh peningkatan jumlah angkatan kerja di Indonesia (Julianto, Kompas.com). Mahasiswa sebagai generasi penerus bangsa turut menyumbangkan angka pengangguran di Indonesia karena mahasiswa merupakan calon angkatan kerja yang belum pasti mendapatkan pekerjaan yang sesuai dengan jurusan atau keinginan mereka.

Berdasarkan hal tersebut diatas perlu dibangun semangat kewirausahaan untuk meningkatkan ketersediaan lowongan pekerjaan. Salah satu penyebab masalah pengangguran terdidik dari universitas adalah banyaknya alumni hanya bertujuan untuk mencari pekerjaan bukan menciptakan lapangan pekerjaan.Hal ini sangat memprihatinkan,khususnya pada lulusan universitas. Salah satu cara yang dapat digunakan untuk menekan jumlah pengangguran adalah dengan menciptakan lapan gan pekerjaan sendiri melalui kegiatan kewirausahaan.

Kewirausahaan merupakan proses dinamis dalam menciptakan tambahan kekayaan. Kekayaan ini dihasilkan oleh individu yang memiliki risiko utama dalam hal modal, waktu dan komitmen karir atau menyediakan nilai bagi beberapa produk dan jasa.Keberadaan kewirausahaan dalam dunia pendidikan sangatlah penting untuk menumbuhkan dan mengembangkan jiwa dan perilaku wirausaha.Para pelaja $\mathrm{r}$ terlebih mahasiswa sekarang dituntut untuk dapat memanfaatkan ilmu yang diperolehnya dibangku kuliah untuk menciptakan kegiatan wirausaha.Kementrian Riset dan Teknolologi serta Pendidikan Tinggi (Kemenristek) sebagai lembaga pemerintah y ang membawahi seluruh perguruan tinggi di Indonesia juga mendukung pengembangan program kewirausahaan bagi para mahasiswa. Hal ini dibuktikan dengan diluncurkannya Program Mahasiswa Wirausaha (PMW) yang bertujuan untuk memberikan bekal pengetahuan, sikap dan jiwa entrepreneuer kepada para mahasiswa. Setiap perguruan tinggi diharapkan mampu mempersiapkan masa depan yang lebih baik 
dengan mengembangkan intelektual dan keterampilan agar generasi muda dapat melakukan aktualisasi diri. Dengan demikian peran perguruan tinggi dih arapkan dapat meningkatkan efikasi diri yang berguna dalam masyarakat dan dunia kerja.

Efikasi diri merupakan keyakinan individu terhdap yang dimiliki untuk memobilisasi motivasi, sumber daya kognitif dan tindakan yang dilakukan atas situasisituasi yang dihadapi. Dengan kata lain efikasi diri adalah penilaian terhadap kemampuan dirinya sendiri. Menurut Bandura efikasi dire adalah key akin an individu tentang kemampuan melakukan suatu tindakan yang diperlukan untuk menc apai suatu hasil.Efikasi diri berhubungan denga keyakinan bahwa dire memiliki kemampuan melakukan tindakan yang diharapkan.

Minat berwirausaha menurut Fuadi adalah keinginan, ketertarikan serta ke sediaan untuk bekerja keras atau berkemauan keras untuk berusaha secara maksimal untuk memenuhi kebutuhan hidupnya tanpa merasa takut dengan resiko yang akan terjadi.Minat menjadi wirausaha didefinisikan sebagai keinginan seseorang untuk bekerja mandiri (self employed) atau menjalankan usahanya sendiri (Rosmiati, Donny, Munawar).

Gagal dalam berwirausaha menjadi salah satu kurangnya keyakinan mahasiswa untuk menjalani kewirausahaan. Dengan kurangnya keyakinan tersebut akan berdampak dengan kesulitan dalam menjalani usahanya. Keyakinan yang kurang terhadap usaha yang dijalani tergantung pemahaman kemampuan dirinya terhadap situasi yang dihadapinya ketika menjalankan usaha. Selain itu kurangnya minat mahasiswa dalam berwirausaha dikhawatirkan akan menambah jumlah pengangguran di Indonesia, mengingat banyaknya jumlah lapangan kerja yang tidak sebanding dengan jumlah pencari kerja.

Berdasarkan latar belakang diatas, maka dapat dirumuskan masalah penelitian sebagai berikut:(1)Apakah terdapat pengaruh positif pendidikan kewirausahaan terhadap minat berwirausaha?, (2) Apakah terdapat pengaruh positif efikasi diri wirausaha terhadap minat berwirausaha?, (3)Apakah terdapat pengaruh positif pendidikan kewirausahaan dan efikasi diri terhadap minat berwirausaha?

Tujuan penelitian sebagai berikut untuk mengkaji pengaruh pendidikan kewirausahaan terhadap minat berwirausaha,untuk mengkaji pengaruh efikasi diri 
wirausaha terhadap minat berwirausaha,untuk mengkaji pengaruh pendidikan kewirausahaan dan efikasi diri terhadap minat berwirausaha.

\section{Tinjauan Teoritis}

\section{A. Efikasi Diri Berwirausaha}

Manusia bertindak bergantung pada kondisi lingkungan sekitar, termasuk juga keyakinan kepada dirinya bahwa mereka mampu atau tidak mampu untuk melakukan suatu tindakan. Keyakinan inilah yang nantinya membawa perubahan terhadap lingkungan setelah bertindak. King, Laura A (2010: 412) menyebutkan bahwa, "selfefficacy adalah kepercayaan individu bahwa ia dapat menguasai sebuah situasi dan menghasilkan keluaran yang positif".Efikasi diri memberikan pengaruhi terhadap perilaku seseorang dalam kehidupan sehar-hari. Pengaruh yang ditimbulkan dari adanya efikasi akan membuat seseorang memiliki kebiasaan yang baik. Menurut Alwisol (2008: 287), "efikasi diri adalah persepsi diri sendiri mengenai seberapa bagus diri dapat berfungsi dalam situasi tertentu. Efikasi diri berhubungan dengan keyakinan bahwa diri memiliki kemampuan melakukan tindakan yang diharapkan”. Keyakinan dalam diri manusia tergantung dari manusia tersebut, dapat berupa keyakinan untuk melakukan hal baik atau malah melakukan hal buruk. Efikasi diri berbeda dengan cita-cita. Cita-cita adalah hal yang seharusnya dapat dicapai, sedangkan efikasi diri adalah penilaian kemampuan diri. Jika seseorang memiliki keyakinan pada dirinya untuk melakukan sesuatu hal dengan baik, maka orang tersebut akan berusaha melakukan hal tersebut sebaik mungkin (Azwar, 2012).

Alwisol (2008: 290), menyatakan bahwa setiap individu mempunyai efikasi diri yang berbeda-beda pada situasi yang berbeda, tergantung kepada: (1) Kemampuan yang dituntut oleh situasi yang berbeda itu. (2) Kehadiran orang lain, khususnya saingan dalam situasi itu. (3) Keadaan fisiologis dan emosional: kelelahan, kecemasan, a patis, murung.

\section{B. Minat Berwirausaha}

Minat berwirausaha umum diartikan sebagai minat seseorang untuk memulai usaha miliknya sendiri dimana keinginan ini juga otomatis didorong untuk harapan mendapatkan keuntungan ekonomi. Minat berwirausaha yang kedua berkaitan dengan 
minat seseorang untuk memulai usahanya dan secara besar harapannya untuk membesarkannya mungkin menjadi pemimpin industri, bisnis internasional atau perusahaan publik. Minat bewirausaha yang ketiga yaitu minat untuk memulai usaha untuk mendapatkan otonomi dan sebuah gaya hidup tertentu, mereka cenderung mencari otonomi dan gaya hidup tertentu seperti melakukan apa yang mereka sukai tanpa adanya keinginan untuk investasi cepat kembali dan juga tanpa adanya keinginan untuk pertumbuhan tinggi (Aditia, 2012).

Minat berwirausaha tidak dibawa sejak lahir tapi tumbuh dan berkembang sesuai dengan faktor yang mempengaruhi. Faktor yang mempengaruhi tumbuhnya keputusan untuk berwirausaha merupakan hasil interaksi dari beberapa faktor yaitu karakter kepribadian seseorang dan lingkungannya (Suharti, 2012).

\section{Pengertian Kewirausahaan}

Istilah kewirausahaan atau entrepreneurship berasal dari istilah ekonomi bahasa perancis pada abad ke 17 dan 18. Dalam bahasa perancis diartikan seseorang yang menjalankan proses pemakaman yang berarti seseorang yang menjalankan proyek atau aktivitas yang penting. Pada abad ke 20 seorang ekononom Schumpeter mengatakan bahwa entrepreneur adalah agen perubahan dalam bidang ekonomi, yaitu dengan cara membuka pasar baru dan menciptakan sesuatu yang baru dengan cara yang baru sehingga para entrepreneur mengubah ekonomi menjadi maju (Hisrich, D. Robert, dkk. 2008 \& Slamet, 2012).

\section{Pendidikan Kewirausahaan}

Entrepreuneurship haruslah bisa menjadi disiplin ilmu tersendiri melalui pendidikan. Menurut Musa Asy'ari melalui pendidikaan Islam pembudayaan entreprenuership harus dilakukan yaitu untuk memperkenalkan kemasan fiqih yang bermuatan pemberdayaan ekonomi sebagai bagian kewajiban menjalankan syaria Islam dan perlu adanya pusat-pusat pelatihan dan pemberdayaan wirausaha yang diselenggarakan secara berkelanjutan.

Menurut Soeharto Prawirokusumo, pendidikan kewirausahaan telah diajarkan sebagai disiplin ilmu tersendiri yang independen yang terpisah dari ilmu-ilmu yang lain, disebutkan: (1) Kewirausahaan berisi bidang pengetahuan yang utuh dan nyata, yaitu 
terdapat teori, konsep dan metode ilmiah yang lengkap. (2) Kewirausahaan memiliki dua konsep yaitu posisi permulaan dan perkembangan usaha yang jelas tidak masuk dalam kerangka pendidikan manajemen umum yang memisahkan antara manajemen dan kepemilikan usaha. (3) Kewirausahaan merupakan disiplin ilmu yang memiliki objek tersendiri yaitu kemampuan menciptakan sesuatu yang baru dan berbeda. Menurut Suryana (2009) Kewirausahaan merupakan alat untuk menciptakan pemerataan usaha dan pendapatan atau kesejahteraan rakyat yang adil dan makmur.

\section{METODE PENELITIAN}

Metode penelitian ini menggunakan jenis pendekatan kuantitatif, yang ditujukan untuk menjelaskan pengaruh pendidikan kewirausahaan dan efikasi diri terhadap minat berwirausaha. Dengan menggunakan teknik analisis data dalam penelitian ini adalah analisis regresi linier berganda.Penelitian ini dilakukan karena berdasarkan hubungan satu variabel bebas dengan satu variabel bebas yaitu Pendidikan Kewirausahaan dan Efikasi diri (variabel bebas) dan Minat Berwirausaha (variabel terikat). Metode pengambilan sample dilakukan dengan cara teknik Convenience Sampling. Dalam penelitian ini yang menjadi sample adalah mahasiswa strata I Fakultas Keguruan dan Ilmu Pendidikan (FKIP) prodi Pedididkan Guru Seoklah Dasar (PGSD) Universitas Muhamadiyah Tangerang berjumlah 70 responden dengan asumsi mend apatkan mata kuliah kewirausahaan.

Instrumen penelitian merupakan alat yang digunakan untuk mengumpulkan data dalam penelitian ini berupa kuesioner. Instrumen yang digunakan adala daftar pertanyaan pada lembar angket yang akan dibagikan kepada mahasiswa. Skala pengukuran yang digunakan dalam penelitian ini dengan menggunakan skala likert. 


\section{HASIL DAN PEMBAHASAN}

\section{Uji Asumsi Klasik}

\section{Uji Normalitas}

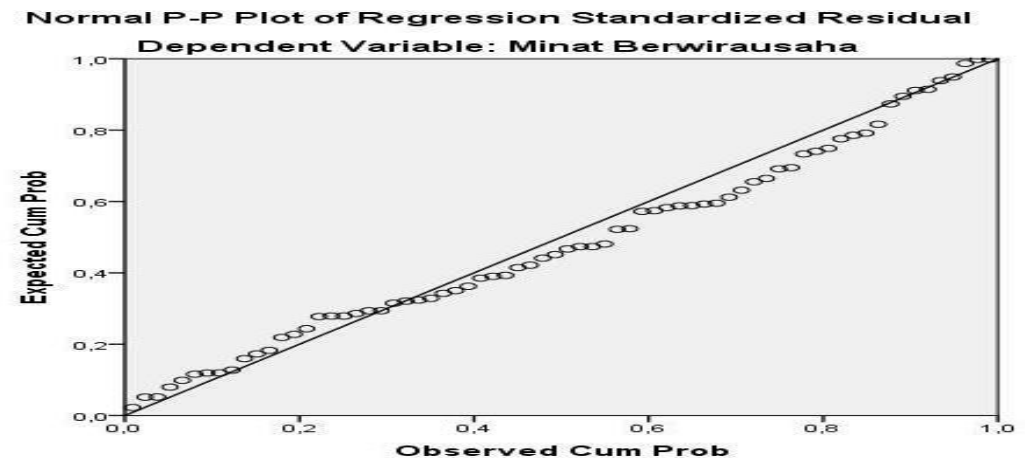

Gambar 1 Uji Normalitas P-Plot

Berdasarkan tampilan grafik hasil uji normalitas P-Plot yaitu terlihat bahwa titiktitik menyebar disekitas garis diagonal, serta penyebarannya mengikuti arah garis diagonal.Hal ini menggambarkan kesimpulan bahwa data yang digunakan dalam penelitian ini normal.Sedangkan pada grafik histogram memberikan pola yang mendekati normal.

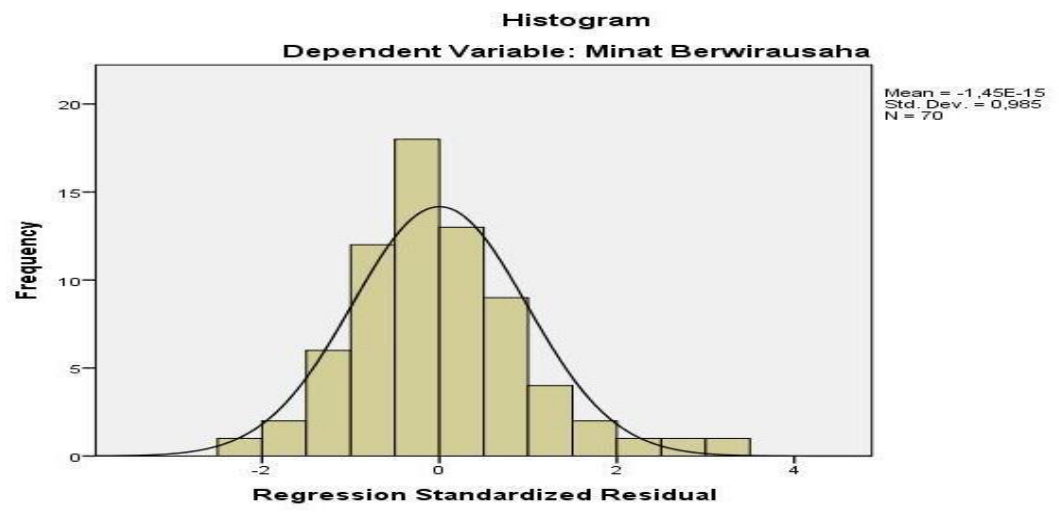

Dengan demikian, dapat disimpulkan bahwa grafik histogram menunjukkan model regresi layak dipakai karena asumsi normalitas. 


\section{Uji Multikolinearitas}

\section{Tabel 1 Uji Multikolinearitas}

\begin{tabular}{|c|c|c|c|c|c|c|c|c|c|c|c|}
\hline \multirow[b]{2}{*}{ Model } & & \multicolumn{2}{|c|}{ Unstandardized Coefificents } & \multirow{2}{*}{$\begin{array}{c}\begin{array}{c}\text { Standardized } \\
\text { Coefficients }\end{array} \\
\text { Betala }\end{array}$} & \multirow[b]{2}{*}{$t$} & \multirow[b]{2}{*}{ Sig. } & \multicolumn{3}{|c|}{ Correlations } & \multicolumn{2}{|c|}{ Collinearity Statisitics } \\
\hline & & B & Sttl. Error & & & & Zero-order & Pattial & Pat & Tolerance & VF \\
\hline & (Constant) & 12,963 & 4,357 & & 2,980 & .004 & & & & & \\
\hline & $\begin{array}{l}\text { Pendidikan } \\
\text { Kewriausahaan }\end{array}$ & .522 &, 165 & 345 & 3,164 &, 002 & 879 & 361 & 249 & .523 & 1,912 \\
\hline & Efikass Diri & 786 & 177 & .484 & 4,438 & 000 & 722 & 477 & 350 & 523 & 1,912 \\
\hline
\end{tabular}

Dari tabel di atas yang menjadi tolak ukur apakah variabel bebas dalam suatu penelitian itu terjadi multikoliniearitas yaitu dengan melihat hasil yang terdapat dalam kolom Colinearity Statisic (tolerance) dan Variance inflation factor (VIF). Berdasarkan tabel diatas penelitian ini tidak terjadi multikoinearitas denga ketentuan sebagai berikut jika nilaitolerance $>0,10$ dan $\mathrm{VIF}<10$, maka dapat diartikan bahwa variabel independen tidak terdapat multikolinieritas.

\section{Uji Heteroskedastis}

Dari grafik di atas, menunjukkan bahwa titik-titik data menyebar secara acak atau tidak teratur di bawah maupun di atas titik orgin (angka 0) pada sumbu Y sehingga dapat disimpulkan bahwa pada penelitian ini data yang digunakan tidak terjadi heterokedastis melainkan homoskedastisitas.Hal ini berarti data termasuk dalam kategori baik dalam penelitian regresi, karena penelitian regresi yang baik tidak terjadi heterosdistisitas.

\section{Uji Determinasi $\left(\mathbf{R}_{2}\right)$}

Tabel 2 Uji Determinasi

\begin{tabular}{|c|c|c|c|c|c|c|c|c|c|}
\hline \multirow[b]{3}{*}{ Model } & \multirow[b]{3}{*}{$R$} & \multirow[b]{3}{*}{ RSquare } & \multicolumn{7}{|c|}{ Model Summary b } \\
\hline & & & \multirow[b]{2}{*}{$\begin{array}{l}\text { Adjusted R } \\
\text { Square }\end{array}$} & \multirow[b]{2}{*}{$\begin{array}{l}\text { Std. Erroro of } \\
\text { the Estimate }\end{array}$} & \multicolumn{5}{|c|}{ Change Statistics } \\
\hline & & & & & $\begin{array}{l}\text { RSquare } \\
\text { Change }\end{array}$ & F Change & 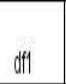 & $d f_{2}$ & Sig. FChange \\
\hline 1 &, $764^{8}$ & .583 & .571 & 4,872 & .583 & 46,930 & 2 & 67 & .000 \\
\hline
\end{tabular}

Dari tabel, nilai koefisien determinasi $\left(\mathrm{R}^{2}\right)$ adalah 0,571 . Hal ini menunjukkan bahwa minat berwirausaha dapat dijelaskan oleh variabel pendidikan kewirausahaan 
dan efikasi diri sebesar $57,1 \%$ dan sisanya $42,9 \%$ dapat dijelaskan dengan pengaruh lainnya yang tidak diteliti dalam penelitian ini.

\section{Uji Hipotesis Penelitian}

Dalam penelitian ini, peneliti menguji hipotesis penelitian dengan teknik analisis regresi berganda menggunakan SPSS 21.Uji regresi berganda ini dilakukan untuk menjawab hipotesis penelitian yang telah di ajukan.

a. Hasil Uji Signifikansi Koefisien Regresi Berganda secara parsial (Uji T)

Tabel3 Hasil Uji T Secara Parsial

\begin{tabular}{|c|c|c|c|c|c|c|}
\hline \multirow[b]{2}{*}{ Model } & & \multicolumn{2}{|c|}{ Unstandardized Coefficients } & \multirow{2}{*}{$\begin{array}{c}\begin{array}{c}\text { Standardized } \\
\text { Coefficients }\end{array} \\
\text { Beta } \\
\end{array}$} & \multirow[b]{2}{*}{$t$} & \multirow[b]{2}{*}{ Sig. } \\
\hline & & $B$ & Std. Error & & & \\
\hline \multirow[t]{3}{*}{1} & (Constant) & 12,983 & 4,357 & & 2,980 &, 004 \\
\hline & $\begin{array}{l}\text { Pendidikan } \\
\text { Kewirausahaan }\end{array}$ & ,522 & 165 & 345 & 3,164 & , 002 \\
\hline & Efikasi Diri &, 786 & 1777 & ,484 & 4,438 &, 000 \\
\hline
\end{tabular}

a. Dependent Variable: Minat Berwirausaha

Bagian ini menggambarkan persamaan regresi untuk mengetahui angka konstan uji hipotesis signifikansi koefisien regresi:

$\mathrm{Y}=12,983+0,522 \mathrm{X} 1+0,786 \mathrm{X} 2$

Dimana:

$\mathrm{Y}=$ Jumlah Minat Berwirausaha

$\mathrm{X} 1=$ Pendidikan Kewirausahaan

$\mathrm{X} 2=$ Efikasi Diri

Pada persamaan di atas menunjukan nilai konstanta sebesar 12,983. Hal ini menjelaskan bahwa tidak ada kenaikan nilai dari variabel independen, maka nilai minat berwirausaha (Y) adalah 12,983.Koefisien regresi pada variabel pendidikan kewirausahaan sebesar 0,522 sehingga dapat diartikan setiap penambahan (karena tanda +) satu skor atau nilai pendidikan kewirau sahaan akan memberi kenaikan skor sebesar 0,522 satuan.Koefisien regresi pada variabel efikasi diri sebesar 0,786 sehingga dapat diartikan setiap penambahan (karena tanda + ) satu skor atau nilai pendidikan kewirausahaan akan memberi kenaikan skor sebesar 0,786 satuan.

Kemudian Uji t dilakukan untuk menguji signifikansi konstanta dan variabel dependen (Minat Berwirausaha). Tabel diatas memperlihatkan koefiesien variabel pendidikan kewirausahaan dengan nilai $\operatorname{Sig}=0,002$ sehingga lebih kecil dari nilai probabillitas 0,05 atau $0,05 \geq 0,002$, maka Ha diterima dan Ho ditolak sehingga dapat 
disimpulkan pendidikan kewirausahaan berpengaruh secara signifikan terhadap minat berwirausaha. Dan untuk koefisien variabel efikasi diri dengan nilai Sig $=0,000$ sehingga lebih kecil dari nilai probabilitas 0,05 atau $0,05 \leq 0,000$, maka Ha diterima dan Ho ditolak sehingga dapat disimpulkan efikasi diri berpengaruh signifikan terhadap minat berwirausaha.

b. Hasil Uji Signifikansi Koefisien Regresi Berganda Secara Menyeluruh (Uji F)

\section{Tabel 4 Hasil Uji F}

$\mathrm{ANOVA}^{\mathrm{a}}$

\begin{tabular}{|c|c|c|c|c|c|c|}
\hline Mode & & $\begin{array}{l}\text { Sum of } \\
\text { Squares }\end{array}$ & df & Mean Square & $\mathrm{F}$ & Sig. \\
\hline \multirow[t]{3}{*}{1} & Regression & 2228,104 & 2 & 1114,052 & 46,930 &, $000^{b}$ \\
\hline & Residual & 1590,482 & 67 & 23,739 & & \\
\hline & Total & 3818,586 & 69 & & & \\
\hline
\end{tabular}

a. Dependent Variable: Minat Berwirausaha

b. Predictors: (Constant), Efikasi Diri, Pendidikan Kewirausahaan

Pada tabel tersebut, menunjukan hasil Uji F yang terdapat dalam kolom F yaitu sebesar 46,930 dengan tingkat signifikansi 0,000. Karena nilai probabilitas 0,05 atau $0,05 \geq 0,000$ maka Ha diterima Ho ditolak artinya koefisien regresi signifikan. Disimpulkan bahwa pendidikan kewirausahaan dan efikasi diri berpengaruh secara simultan dan signifikan terhadap minat berwirausaha.

\section{Pembahasan}

Berdasarkan hasil uji hipotesis penelitian, dapat dilihat variabel pendidikan kewirausahaan $\operatorname{Sig}=0,002$ lebih kecil dari nilai probabillitas 0,05 atau 0,05 $\geq 0,002$, maka Ha diterima dan Ho ditolak artinya koefisien regresi sinifikan. Dapat disimpulkan bahwa pendidikan kewirausahaan berpengaruh terhadap minat berwirausaha sebesar $52,2 \%$ mempengaruhi minat berwirausaha, sisanya minat berwirausaha dipengaruhi oleh faktor-fakor lainnya. Adanya pengaruh antara pendidikan kewirausahaan terh adap minat berwirausaha dalam penelitian ini mengandung pengertian bahwa semakin tinggi pendidikan kewirausahaan yang mempelajari keahlian penting yang dibutuhkan maka akan semakin besar minat untuk berwirausaha.

Efikasi diri memiliki probabilitas dengan nilai $\operatorname{Sig}=0,000$ sehingga lebih kecil dari nilai probabilitas 0,05 atau $0,05 \leq 0,000$, maka Ha diterima dan Ho ditolak sehingga 
dapat disimpulkan efikasi diri berpengaruh signifikan terhadap minat berwirausaha. Efikasi diri dalam penelitian ini berdimensi tingkat, kekuatan dan generalisasi memiliki pengaruh terhadap minat berwirausaha sebesar 78,6\%. Pengaruh efikasi diri terhadap minat berwirausaha melingkupi beberapa faktor sesuai dengan teori Bandura tentang efikasi diri yang juga disebutkan dalam penelitian Ellen A. Drost, dimana faktor-faktor ini mempengaruhi efikasi diri terhadap minat berwirausaha seperti (1) Sifat tugas yang dihadapi sehingga menuntut kinerja y ang lebih sulit dan berat daripada tugas yang lain, (2) Intensif eksternal yang diberikan orang lain untuk merefleksikan keberhasilan seseorang seperti orang tua, tokoh masyarakat dan panutan, (3) Status individu dalam lingkungan derajat sosial seseorang, mempengaruhi penghargaan dari orang lain dan rasa percaya dirinya, (4) Informasi tentang kemampuan dirinya dimana positif atau negatif akan mempengaruhi efikasi diri seseorang.

Pendidikan kewirau sahaan dan efikasi diri memilliki pengaruh y ang signifikan yaitu sebesar $57,1 \%$. Sisanya minat berwirau saha dapat dipengaruhi oleh as pek -as pek y ang lain, yang disebutkan dalam penelitian sebelumnya yang berjudul Fostering Entrepreneurship among Finnish Business Students: Antecendents of Entrepreneurial Intent and Implications for Entrepreneuship Education olehEllen A. Drost et al yang menjadi acuan dalam penelitian ini yaitu pengalaman berwirausaha dan kepribadian proaktif dimana dalam penelitian tersebut dijelaskan bahwa pengalaman berwirausaha dan kepribadian proaktif mempengaruhi efikasi diri terhadap minat berwirausaha.

\section{SIMPULAN DAN SARAN}

Berdasarkan hasil penelitian uji hipotesis dengan menggunakan analisis regresi berganda, dapat ditarik kesimpulan sebagai berikut :

1. Terdapat pengaruh positif signifikan pendidikan kewirausahaan terhadap minat berwirausaha mahasiswa Fakultas PGSD Universitas Muhamadiyah Tangerang sebesar 52,2\% dengan nilai signifikan 0,002. Pendidikan kewirausahaan yang dimaksud disini seperti penguasaan dalam keahlian yang dibutuhkan yaitu mengenali peluang-peluang bisnis baru, mengevaluasi peluang-peluang, memulai sebuah bisnis dan organisasi kewirausahaan yang dimana keahlian-keahlian itu didapat dari pendidikan kewirausahaan yang tidak hanya melalui disiplin ilmu melainkan juga berasal dari kursus, seminar kewirausahaan dan pengalaman 
akademik. Pendidikan kewirausahaan memiliki pengaruh yang sangat signifikan terhadap minat berwirausaha.

2. Terdapat pengaruh positif signifikan efikasi diri terhadap minat berwirausaha mahasiswa Fakultas PGSD Universitas Muhamadiyah Tangerang sebesar 78,6\% dengan nilai signifikan 0,000. Pengaruh positif yang signifikan memberikan dampak yang positif juga terhadap minat berwirausaha. Faktor-faktor efikasi diri yang mempengaruhi minat berwirausaha berasal dari sifat tugas yang dihadapi, persuasif eksternal, status sosial dan kemampuan diri.

3. Hasil studi menunjukkan bahwa ketika dilakukan pengujian variabel secara simultan (bersama-sama) dengan menggunakan analisis regresi linier berganda, ditemukan bahwa variabel pendidikan kewirausahaan dan efikasi diri secara simultan memiliki pengaruh positif signifikan terhadap minat berwirausaha mahasiswa Fakultas PGSD Universitas Muhamadiyah Tangerang sebesar 57,1\%. Pengaruh positif tersebut menunjukan bahwa pendidikan kewirausahaan dan efikasi diri dapat menjadi faktor yang penting untuk minat berwirausaha. Keduanya berpengaruh secara signifikan terhadap minat berwirausaha dimensinya yaitu umum, gaya hidup dan pertumbuhan tinggi.

\section{Saran}

1. Pada pendidikan kewirausahaan, menjadikan mata kuliah kewirausahaan menjadi mata kuliah wajib di setiap jurusan di seluruh fakultas di Universitas Muhamadiyah Tangerang, namun mata kuliah kewirausahaan juga sebagai mata kuliah praktek sehingga dapat meningkatkan kemampuan dan kepercayaan diri menjadi seorang wirausaha.

2. Memprogramkan kegiatan ke kurikulum pendidikan untuk studi langsung ke wirausaha sukses (perusahaan/organisasi sukses), magang, menulis tentang kewirausahaan.

3. Penelitian ini menunjukkan terdapat variabel lain sebesar $42,9 \%$ yang mempengaruhi minat berwirausaha. Dengan demikian akan lebih lengkap jika diadakan penelitian lagi untuk dapat melakukan uji lebih lanjut mengenai variabel variabel lainnya. 
4. Penelitian selanjutnya dapat mengombinasikan antara pernyataan yang bersifat tertutup dan terbuka sehingga peneliti dapat memperoleh gambaran yang lebih mendalam tentang berbagai hal yang ingin diteliti. Untuk alat ukur variabel dalam penelitin selanjutnya dapat menyertakan alasan mengapa memiliki pilihan tersebut pada masing-masing item pernyataan sehingga eksplorasi data tidak dibatasi.

5. Penelitian mendatang sebaiknya ke lingkup yang lebih luas lagi seperti mahasis wa secara umum di seluruh indonesia dan lebih diidentifikasikan jenis-jenis wirausaha yang berada di setiap fakultas, memvalidasi perbedaan-perbedaan dan mengidentifikasi prediktor-prediktor unik.

\section{DAFTAR PUSTAKA}

Aditia Putra, Rano. (2012). Faktor-Faktor Penentu Minat Mahasiswa Manajemen Untuk Berwirausaha (Studi Mahasiswa Manajemen FE UNP). Jurnal Manajemen. Vol. 1.

Alwisol. (2008). Psikologi Kepribadian. Edisi Revisi. Malang: UMM Press

Azwar, S. (2012). Efikasi Diri dan Prestasi Belajar Statistik Pada Mahasiswa. Jurnal Psikologi. No. I.

Asy’arie, Musa. (1997). Islam etos Kerja \& Pemberdayaan Ekonomi Umat, Yogyakarta: LESFI.

Bandura, Albert. (1997). Self-efficacy: Toward a Unifying Theory of Behavioral Change. Psychological Review.

Creswell, John. (2015). Riset Pendidikan (terjemahan). Edisi V. Yogyakarta: Pustaka Pelajar.

Drost, Ellen A. et. al. (2011) "Fostering Entrepreneurship among Finnish Business Students: Antecendents of Entrepreneurial Intent and Implications for Entrepreneuship Education", International Review of Entrepreneurship.

Fuadi, Iski Fadli. (2009). Hubungan Minat Berwirausaha dengan Prestasi Praktik Kerja Industri Siswa Kelas XII Teknik Otomotif SMK Negri 1 Adiwerna Kabupaten Tegal. Jurnal PTM.Vol 9.

Hisrich, D. Robert, dkk. (2008). Entrepreneurship. Edisi 7. Jakarta: Salemba Empat.

Lo Choi Tung. (2011). The Impact of Entrepreneurship Education on EntrepreneurialIntention of Engineering Students. City University of Hong Kong. 
Julianto, Pramdia Arhando. (2017). Di akses pada Agustus 2017, Jumlah Pengangguran Naik Menjadi 7,04 Juta Orang. https://ekonomi.kompas.com/read/2017/11/06/153940126

Rosmiati, dkk. (2015). Sikap, Motivasi dan Minat Berwirausaha Mahasiswa. Jurnal Manajemen dan Kewirausahaan.Vol. 17.

Schumpeter, Joseph (1951) "Change and the Entrepreneur" in Essays of J.A. Schumpeter. Ed. Richard V. Clemence (Reading). Mass: Addison Wesly.

Slamet, Franky dkk. (2014). Dasar-dasar kewirausahaan: Teori \& Praktik. Jakarta: PT. Indeks.

Soeharto, Prawirakusumo. (1997). "Peranan Perguruan Tinggi dalam Menciptakan wirausaha-wirausaha tangguh", Makalah dalam seminar, Jatinangor: PIBIIKOPIN dan FNSt.

Sudamarto, R. Gunawan. (2013). Statistik Terapan Berbasis Komputer denganProgram IBM SPSS 19. Jakarta: Penerbit Mitra Wacana Media.

Sugiyono. (2011). Metode Penelitian Kuantitatif Kualitatif dan R\&D. Bandung: Alfabeta.

Suharti L \& Sirine H. (2012). Faktor-Faktor yang mempengaruhi Terhadap Niat Kewirausahaan (Studi Lapangan Mahasiswa Universitas Kristen Satya Kencana Salatiga). Jurnal Manajemen dan Kewirausahaan.

Sunyoto, Danang. (2011). Metodologi Penelitian Ekonomi. Yogyakarta: CAPS.

Suryana. (2009). Kewirausahaan Pedoman Praktis: Kiat dan Proses Menuju Sukses. Jakarta: Salemba Empat. 